\title{
Cardiac tamponade due to peripheral inserted central catheter in newborn
}

\author{
Tamponamento cardíaco causado por cateter central de inserção periférica em recém-nascido \\ Maria Fernanda Pellegrino da Silva Dornaus ${ }^{1}$, Maria Aparecida Portella ${ }^{1}$, Arno Norberto Warth ${ }^{2}$, Rosana Aparecida \\ Lacava Martins' ${ }^{2}$ Mauricio Magalhães ${ }^{1}$, Alice D’Agostini Deutsch ${ }^{1}$
}

\begin{abstract}
This article reports the case of an adverse event of cardiac tamponade associated with central catheter peripheral insertion in a premature newborn. The approach was pericardial puncture, which reversed the cardiorespiratory arrest. The newborn showed good clinical progress and was discharged from hospital with no complications associated with the event.
\end{abstract}

Keywords: Catheters; Cardiac tamponade; Infant, newborn; Infant, premature; Case reports

\section{RESUMO}

Este artigo relata um evento adverso de tamponamento cardíaco associado a cateter central de inserção periférica em recém-nascido prematuro. A abordagem foi punção pericárdica que reverteu 0 quadro de parada cardiorrespiratória. 0 recém-nascido apresentou boa evolução clínica e recebeu alta hospitalar sem complicações associadas ao evento.

Descritores: Cateteres; Tamponamento cardíaco; Recém-nascido; Prematuro; Relatos de casos

\section{INTRODUCTION}

Peripherally inserted central catheters (PICC) are routinely inserted in Neonatal Intensive Care Units (NICU). The tip of the catheter should be located in the inferior third of the superior vena cava, confirmed by radiography before beginning intravenous infusions ${ }^{(1-3)}$. Dislocation or inadequate positioning of the catheter tip may cause perforation of structures and pericardial infusion. Although cardiac tamponade is a rare complication, it leads to high mortality ${ }^{(1-5)}$.
This study reports the case of cardiac tamponade associated with PICC in a premature newborn.

\section{CASE DESCRIPTION}

A male newborn, birth weight $1290 \mathrm{~g}$, gestational age 30 weeks and 2 days, with indication for PICC on the fourth day of life. After measuring the length of the insertion site up to the second intercostal space, the catheter was inserted into a cephalic vein. After insertion, a radiography was taken and $4 \mathrm{~cm}$ of the catheter were tractioned; on the $6^{\text {th }}$ day of life, a new radiographic image was made, and the catheter was pulled another $4 \mathrm{~cm}$.

On the $9^{\text {th }}$ day of life, the newborn presented with episodes of bradycardia, drop in saturation, cyanosis and dyspnea and continuous positive airway pressure (CPAP) was installed. With worsening of the clinical condition, he was intubated and cardiopulmonary resuscitation (CPR) was initiated, with a good response. The bradycardia recurred, and CPR was reinitiated. The radiography showed a discreet enlargement of the cardiac area and the tip of the catheter in a cardiac chamber.

Considering the hypothesis of cardiac tamponade, an echocardiogram was requested and revealed pericardial effusion with signs of tamponade. Cardiac puncture under echocardiographic visualization extracted 25 $\mathrm{mL}$ of yellowish fluid, similar to parenteral solution. Immediate clinical improvement was noted. The tip of the catheter was repositioned in the superior vena cava and confirmed by radiography. The catheter was maintained in use for another 8 days.

\footnotetext{
Neonatal Unit, Hospital Israelita Albert Einstein - HIAE, Sao Paulo (SP), Brazil.

${ }^{2}$ Neonatal Intensive Care Unit, Hospital Israelita Albert Einstein - HIAE, Sao Paulo (SP), Brazil.

Correspondence: Maria Fernanda Pellegrino da Silva Dornaus - Avenida Albert Einstein, 627/701 - Morumbi - CEP 05651-901 - São Paulo (SP), Brasil - Tel.: 11 21512787 - E-mail: ma_fernanda@einstein.br

Received on: Sep 21, 2010 - Accepted on: Jul 29, 2011

Conflicts of interest: none
} 
Twenty-four hours after the event, the newborn was extubated and the vasoactive drugs were discontinued. The echocardiogram performed two and four days after the event confirmed the absence of pericardial effusion. Brain ultrasonographies were performed 24 hours after the event and upon discharge and were normal. The newborn was discharged on the $31^{\text {st }}$ day of life.

\section{DISCUSSION}

The hypothesis of tamponade should be considered for any newborn with PICC presenting bradycardia, hypotension, drop in saturation or cardiac arrest, particularly if not preceded by respiratory failure ${ }^{(1-6)}$. The infusion of a small volume may cause tamponade due to the reduced size of the heart ${ }^{(1,2)}$. Radiology images may not show enlarged cardiac silhouette. The echocardiogram confirms the diagnosis and aids in the emergency pericardiocentesis, the only effective measure to avoid death. The high mortality rate is associated with the delayed diagnosis, and achieves a rate of $75 \%$ when pericardiocentesis is not performed ${ }^{(5)}$.

The location of the catheter in the distal portion of the superior vena cava, external to the cardiac area, should be confirmed by radiography after insertion and before beginning intravenous infusion ${ }^{(1-10)}$. Camargo et al. observed that, after insertion of the PICC, $48.2 \%$ had been placed in the right atrium and needed to be repositioned $^{(10)}$.

The tip of the catheter may migrate and subsequent radiological images frequently show it in other positions different from that verified at insertion ${ }^{(2,5-10)}$.

Changing arm position has a significant influence in the location of the catheter tip, moving it between 2.2 and 3.5 intercostal spaces. This movement takes place regardless of the catheter having been inserted via the cephalic or basilic veins, left or right upper limbs, or inserted above or below the elbow. The highest position is achieved upon insertion with the patient's arm at a $90^{\circ}$ angle and the elbow extended. When the X-ray is interpreted, one should consider that the position for the test differs from that of flexion which the newborn normally takes ${ }^{(9)}$.

In order to prevent migration of the tip of the catheter, movements of the arm with the catheter, head, and neck of the newborn should be minimized. Every movement and every flexion may advance the tip of the catheter towards the interior of the heart and may cause perforation $^{(4)}$. It is recommended that the position of the catheter tip be periodically checked by X-rays and when requested for other clinical reasons ${ }^{(1-3,6,7)}$.

Migration of the catheter to the cardiac chamber plays a significant role in complications and risk of death. Pericardial effusion and cardiac tamponade may occur as a result of right perforation or endocardial tissue lesion due to infusion of hypertonic solution or due to adherence of the catheter tip to the myocardium, with the formation and dislocation of a thrombus ${ }^{(1,5)}$.

Cardiac tamponade associated with PICC is a rare event with an incidence of 0.76 to $3.0 \%$. Nadroo et al. observed an incidence of $0.76 \%$ in deaths due to cardiac tamponade, corresponding to three deaths in 390 PICCs inserted. In a study conducted in 83 NICU in the United States, in $23 \%$ at least one death observed was due to perforation or myocardial arrhythmia, and in $82 \%$, due to migration of the catheter ${ }^{(2)}$. Beardsall et al. estimated the risk of tamponade associated with PICC at 1.8 per 1000 catheters, corresponding to $0.2 \%$ of newborns with PICC, with a mortality rate of 0.7 per 1000 newborns $^{(6)}$.

Tamponade may occur at any moment, with cases described between 3 hours and 6 days after the procedure $^{(1-5)}$. It may not be necessary to remove the catheter after pericardiocentesis ${ }^{(5)}$.

\section{CONCLUSION}

This was the first serious adverse event (SAE) since 2001, when the use of PICC was initiated at the NICU. The event was analyzed and presented during the meeting of SAEs of the institution. Improvements in assistance were implemented, such as a strict analysis of indication for catheter, radiographies to confirm positioning and after pulling the catheter, documentation of the catheter tip position on X-rays performed during hospitalization and removal of the catheter as soon as possible.

Establishing measures for improving care processes helps reducing complications associated with NICU procedures, and are essential in treatment of premature newborn.

\section{REFERENCES}

1. Kabra NS, Kluckow MR. Survival after an acute pericardial tamponade as a result of percutaneously inserted central venous catheter in preterm neonate. Indian J Pediatr. 2001;68(7):667-80.

2. Nadroo AM, Lin J, Green RS, Magid MS, Holzman IR. Death as a complication of peripherally inserted central catheters in neonates. J Pediatr. 2001;138:599-601.

3. Camara D. Minimizing risks associated with peripherally inserted central catheters in the NICU. Am J Maternal Child Nurs. 2001;26(1);17-22.

4. Yoder D. Cardiac perforation and tamponade: the deadly duo of central venous catheters. Int J Trauma Nurs. 2001;7(3):108-12.

5. Nowlen TT, Rosenthal GL, Johnson GL, Tom D J, Vargo TA. Pericardial effusion and tamponade in infants with central catheters. Pediatrics. 2002;110(1 Pt 1):137-42.

6. Beardsall k, White DK, Pinto EM, Kelsall AWR. Pericardial effusion and cardiac tamponade as complications of neonatal long lines: are they really a problem? Arch Dis Child Fetal Neonatal Ed. 2003;88(4):F292-5. 
7. Nadroo AM, Glass RB, Lin J, Green RS, Holzman IR. Changes in upper extremity position cause migration of peripherally inserted central catheters in neonates. Pediatrics. 2002;110(1 Pt 1);131-6.

8. Rastogi S, Bhutada A, Sahni R, Berdon WE, Wung Jen-Tie. Spontaneous correction of the malpositioned percutaneous central venous line in infants. Pediatr Radiol.1998;28(9):694-6.
9. Connolly B, Amaral J, Walsh S, Temple M, Chairt P, Stephens D. Influence of arm movement on central tip location of peripherally inserted central catheters (PICC). Pediatr Radiol. 2006;36(8):845-50.

10. Camargo PP, Kimura AF, Toma E, Tsunechiro MA. Localização inicial da ponta de cateter central de inserção periférica (PICC) em recém-nascidos. Rev Esc Enferm USP. 2008;42(4):723-8. 